UDC 579.62.619

DOI: $10.15587 / 2519-8025.2018 .124837$

\title{
THE NATURE OF THE SPREAD OF PORCINE CIRCOVIRUS TYPE 2 AS AN EMERGING IN UKRAINE DURING THE PERIOD FROM 2007 TO 2012
}

\author{
(c) L. Dudar, V. Polishchuk, I. Sobko, I. Budzanivska
}

В статті підсумовуються результати, отримані иляхом вивчення патологічного матеріалу в період з 2007 по 2012 рр. на наявність ичирковірусу свиней 2 типу. Наші результати показують, щзо основна територія де циркулює PCV-2 в Украӥні - це Тернопільська (80\%), Кіровоградська (60\%), Віннищька (57\%) та Дніпропетровська (52\%) області

Ключові слова: інфекція свиней, ичрковірус свиней 2 типу (PCV-2), синдром мультисистемного виснаження поросят, ПЛР

\section{Introduction}

Ukraine is considered as a "hotspot" for emerging infectious diseases (EIDs) of pigs, meaning that it is a high-risk country for new infectious diseases to transmit. The pig production is highly increasing in Ukraine and many of breeding pigs have been coming from different countries, infected by different pathogens. Porcine circovirus 2 (PCV-2) is a ubiquitous virus and causal agent of well-known porcine multisystemic wasting syndrome (PMWS) and other PCV-2assocciated diseases. This is a virus of Circoviridae family, which is non-enveloped, circular, singlestranded DNA virus $[1,2]$.

\section{Literature review}

Porcine circovirus (PCV), which belongs to the family Circoviridae, genus Circovirus [1], is one of the smallest animal viruses with unenveloped, singlestranded circular genome and a size of $17 \mathrm{~nm}$ in diameter [2, 3]. Two species of PCV, PCV1 and PCV2, have been characterized [4]. PCV1 is considered to be nonpathogenic to pigs by experimental inoculation [1], and has originally been identified as a persistent tissue culture contaminant in pig kidney cell lines [5]. PCV2 has been shown to be the causative agent of the post-weaning multisystemic wasting syndrome (PMWS) of pigs [6, 7].Direct horizontal transmission of PCV-2 is the most important route for infecting susceptible animals and spreading the virus between pigs. The other route of transmission of PCV-2 to naive animals is indirect via oral ingestion of uncooked infected meat [8]. Pigs can shed the virus for a long time and it can be detected in a variety of different excretions: nasal and fecal excretions, serum and lymphoid tissue [4]. PCV-2 is wildly spread among pigs throughout the world, has some genetic variation and has been found in both domestic and wild pigs. This virus is highly persistent in the environment and stable even under high temperatures and under many different $\mathrm{pH}$-values. The virus is also resistant against many common disinfectants such as iodine, alcohol, phenol and formaldehyde [4].

That is why it persistently circulates all over the world, and Ukraine is not exclusion. The clinical signs of circovirus-associated infection of pigs in Ukraine were described from the beginning of 2000s; however, the information about the detection of PCV-2 isolates, their characteristic and distribution in the different regions have not been published yet

Since 2007 the occurrence of the disease, which characterized by the high mortality level of pigs and by the number of specific symptoms appropriate to circovirus-associated syndromes was recorded in different farms $[9,10]$. Therefore, we have conducted a study to identify the causative agent of the mentioned disease.

\section{The aim and objectives of the study}

The aims of this study were to investigate the disease transmission dynamics in the livestock interface in Ukraine with PCV-2 as a model, as a part of the EID surveillance, and estimate the prevalence of PCV-2 in domestic pigs in Ukraine.

To accomplish the set goal, the following tasks were formulated:

1. Identify the virus in animals' samples, based on the types of tissue and organs.

2. Identify PCV-2 in pigs' samples of different age groups from different regions of Ukraine.

\section{Materials and methods}

Samples preparation

The samples of pathological material of 352 animals from 109 farms all over Ukraine were collected during 6 years. The samples of lungs, mesenteric and lymph nodes, small intestine and other tissues were collected during pathology examination after observation of clinical signs like wasting, icteric organs, skin lesions, respiratory and intestine disorders, enlargement and inflammation at least one of lymph nodes, specific for PCV-associative disease in pigs, 35 to 120 days of age. The samples of each tissue were collected into plastic tubes and frozen $-20^{\circ} \mathrm{C}$.

Nucleid acids extraction

DNA extraction from samples that were collected from 2007 to 2009 year has been proceeding by sorbent approach with chloroform-isoamyl and isopropyl acetone washing with DEPC-H2O elution. And extraction from samples from 2010 to 2012 with ready-touse filtrating columns kit «Tissue DNA» (Machery Nagel) according to the manufacturer's instructions.

Primers analysis and optimization

With the aim of PCV-2 genome detection the pair of specific primers, recommended by OIE (Office 
International des Epizooties - World Health Organization in Animal Health, OIE) were used. An optimization and analysis have been done with the help of Vec- tor NTI Advanced 11 and Primer3 v 4.0.0 programs and specific checking was introduced in BLAST NCBI (Table 1).

Table 1

Characteristic of primers, which used for PCR detection PCV-2 genome in the samples of pathological material of pigs in Ukraine carried out during 6 years (from 2007 to 2012). The primers that have been used in the mentioned study were confirmed as highly homologous to matrix sequences to the typical field strain

\begin{tabular}{|c|c|c|c|}
\hline Primer & Orientation & Sequence & Genome position \\
\hline Cir_orf2_F & forward & 5'-ATGGTTACACGGATATTGTAGTCC -3' & $1086-1110$ \\
\hline Cir_orf2_R & reverse & 5'-TCCCGCACCTTCGGATATACTG -3' & $1567-1588$ \\
\hline
\end{tabular}

\section{Polymerase chain reaction}

The PCR amplification using different commercial Taq-polymerases and Master-Mixes was carried out on $3 \mathrm{mcl}$ of DNA extracted from mentioned samples by the ordinary amplification protocol, started with 4 minutes long hot-start denaturation and followed by 35 circles of $30^{\prime}$ denaturation at $95{ }^{\circ} \mathrm{C}, 60$ 'primer annealing at $60{ }^{\circ} \mathrm{C}$ and $30^{\prime}$ of elongation at $72{ }^{\circ} \mathrm{C}$. The DNA fragment (502 bp) produced following PCR was visualized in $1,7 \%$ agarose gel.

\section{Results and discussions}

The characteristic of the pathological anatomy of the animals' state, selected for the study

During the study for identifying PCV-2 the tissue samples from sick animals from 352 pigs from 109 farms of 23 regions of Ukraine and Crimea were analyzed, their morphological, pathological and clinical conditions were described. The materials for the study were taken from pigs that died from the probable infection or were knowingly killed for the diagnostics. All mentioned animals had the external and internal pathological changes specific for PCV-associated pig syndrome.

Thus, we identified the following features in animals' tissues selected for the study: anaemic skin and yellowness (42\%) the animals' weight and age did not match the standards $(70 \%)$, specifically twisted spine $(12 \%)$, hemorrhagic dermatitis $(2 \%)$ and ear necrosis (2\%) (Fig. 1).

During the autopsy of the mentioned animals a great number of pathologicall changes was recorded, such as interstitial pneumonia $(70 \%)$, catarrhal non hemorrhagic enteritis $(41 \%)$, pericarditis $(3 \%)$, bleeding of kidney $(8 \%)$, enlarged spleen $(11 \%)$, increasing of inguinal $(78 \%)$, mesenteric $(52 \%)$, peribronchial $(24 \%)$ liver $(22 \%)$, lymph nodes $(\mathrm{LN})$, yellowness of internal organs (6\%), stomach ulcer (2\%) (Fig. 2).

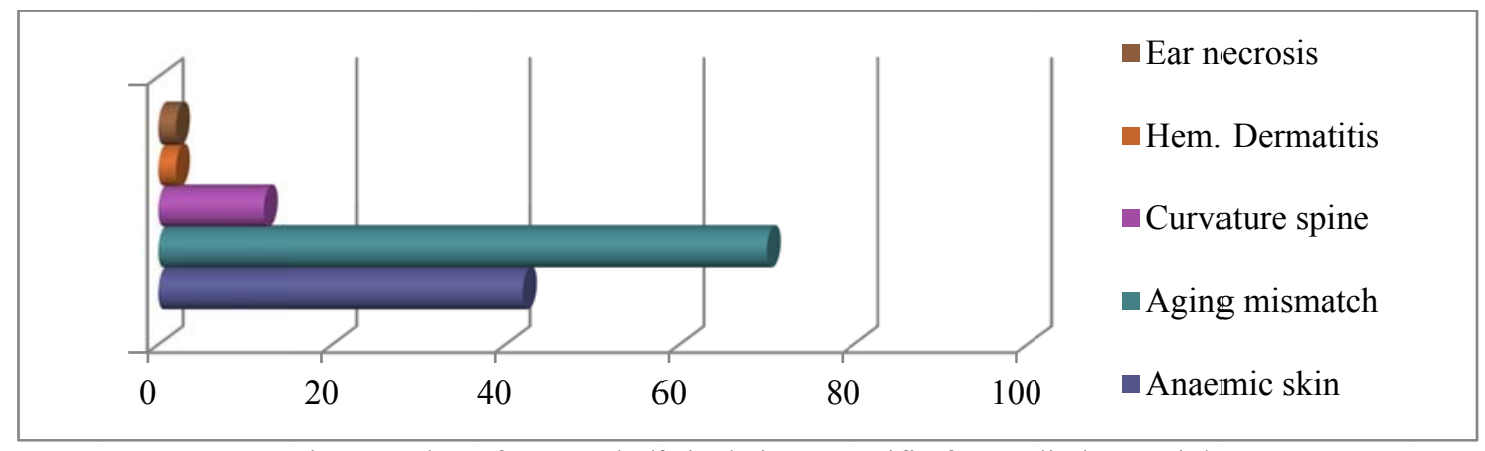

Fig. 1. Index of external clinical signs specific for studied material

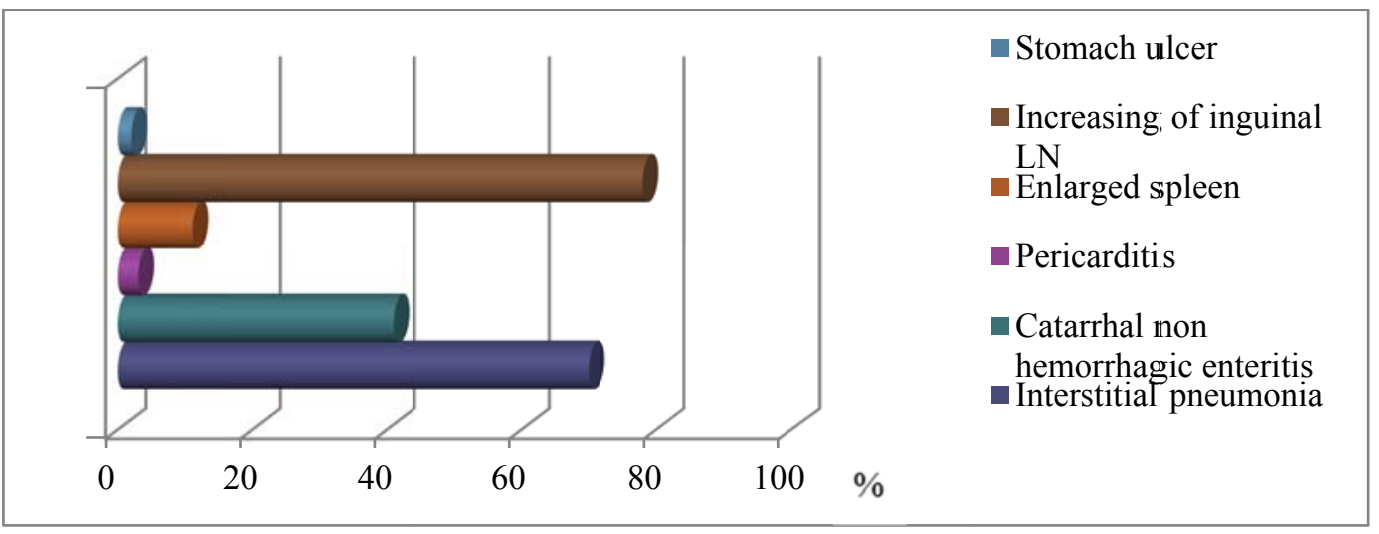

Fig. 2. Index of internal pathological features found in the studied material 
The next stage of our work was to identify the virus in animals' samples, based on the types of tissue and organs. The tissue samples of lungs, intestines, lymph nodes, blood and sperm were studied separately, and the combined studies of lungs and intestines, intestines and lymph nodes, lungs and lymph nodes, lungs, intestines and lymph nodes were carried out. Using the electrophoretic analysis of PCR products, specific products length 1234 p.n. were recorded in 57 samples from various organs and combined samples. Thus, the results of our study revealed the PCV-2 presence in samples of lung tissue in 15 of $37(40.5 \%)$ cases. In- stead, the virus was detected in samples of intestine and lymph nodes in 3 of 3 and 4 of $4(100 \%)$ of the investigated cases, correspondingly. However, only 3 out of $5(60 \%)$ blood samples were positive for PCV-2. In 4 sperm samples the virus was found. In the combined samples of intestines and lymph nodes virus was identified in 2 of $3(66.6 \%)$ cases and in the combined samples of intestines and lungs in 4 of $5(80 \%)$ cases. Also, 10 of $15(66.6 \%)$ samples of combined lungs and lymph nodes were positive for PCV-2 in 16 of 32 $(50 \%)$ of the combined samples of lungs, intestines and lymph nodes (Fig. 3).

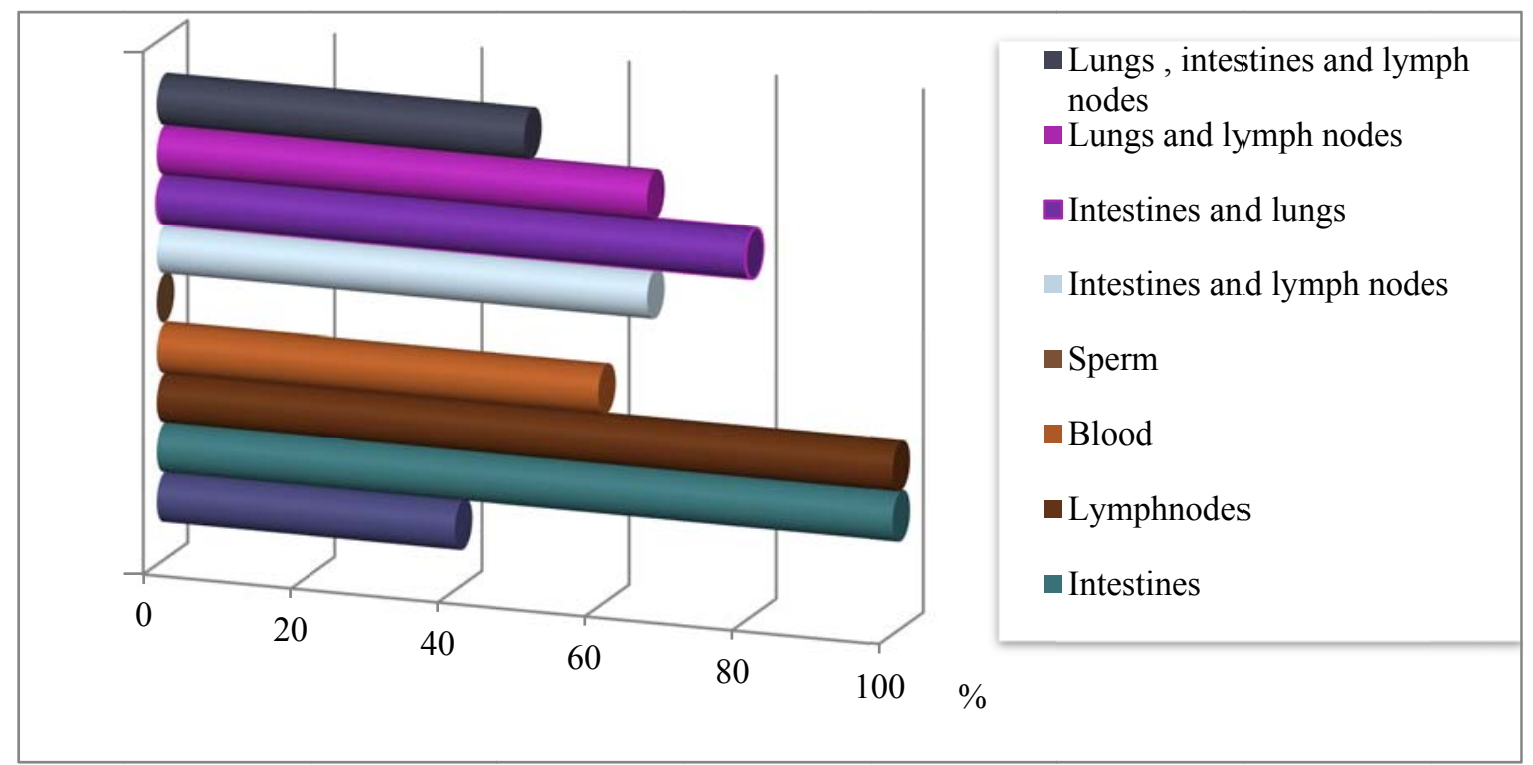

Fig. 3. The PCV- 2 detection dependence from the localization

Identification of $P C V-2$ in pigs' samples of different age groups from different regions of Ukraine

To establish the dependence in pathogen presence and age of the animals, as well as to determine the geographical distribution of the mentioned virus, we first conducted the study with using the DNA isolated from material from different age and location criteria. To ensure the specificity of the reaction, the temperature of primer hybridization was set as $60^{\circ} \mathrm{C}$, and magnesium chloride quantity was 1.7 microliter per sample. In this reaction, we used a set of primers Cir_orf2_F and Cir_orf2_R, which are flanking a specific area of Sar-gene length 502 p.n. As a result, electrophoretic analysis of PCR products demonstrated the presence of specific reaction products in 57 investigated samples from animals of all ages and different regions of Ukraine. The absence of reaction products in the negative control samples, confirmed the adequacy of the results.

Thus, PCV-2 was found in 57 of 108 samples from different age and location groups from 16 of 22 regions of Ukraine. Moreover, from 6 regions of Ukraine, namely Kharkov, Kirovograd, Volyn', Zakarpat'ya, Ternopil', Kherson all samples were positive for PCV-2. Next, from 5 regions of Ukraine, namely Donetsk, Zaporizhzhya, Kiev, Odessa and Sumy, more than $50 \%$ of the samples were positive for virus presence. In material from Vinnitsa, Dnipropetrovs'k, Cherkassy, Chernihiv and Poltava PCV-2 was detected in less than $50 \%$ of the sample. In samples taken from animals in Chernivtsi, Khmelnytsky, Rivne, Mykolaiv, Lugansk, Ivano-Frankivsk are:as the virus was not detected at all.

In 5 weeks aged pigs, the presence of PCV-2 was confirmed in 2 of 13 samples $(15 \%)$. However, in animals of the middle age group (5-16 weeks) PCV-2 was found in 36 of $60(60 \%)$ samples. In the older age group (17-28 weeks) PCV-2 was found in 8 of $12(66,6 \%)$ samples. However, in animals' samples of reproductive age (43104 weeks) virus was identified in 3 of $5(60 \%)$ cases. In addition, it was found in the studied tissue samples from aborted fetuses. In these samples swine circovirus type 2 was found in 2 of $8(25 \%)$ samples.

Thus, summarizing the results, the presence of PCV-2 was proved for all age groups examined, but with varying frequency. Considering this fact, choosing samples from animals of elder aged groups for monitoring the presence of the virus is more appropriate. However, this analysis cannot be used in the cases where material is selected according to the external signs of the disease. In addition, this study confirmed the fundamental possibility of detecting circovirus in tissues of aborted fetuses or stillborn animals that indicates on the transplacental virus transmission.

These results also match a relation between the place of production and PCV-2 presence, but no direct dependence between the presence of the pathogen and the age of the animals. 
In this work, we are identifying PCV-2 in the tissue samples and studying spread of this virus at farms in the different Ukrainian regions. The important fact during the identifying work is that among pigs at the age of 5 weeks the external and internal symptoms were almost absent, except the cases, when weight loss and catarrhal enteritis were observed. However, in pigs aged from 5 to 16 weeks, almost all of the described pathological and anatomical features of circovirusassociated syndrome were present, such as external signs (weight loss, anemic skin), clinical signs of respiratory dysfunction (cough, breath shortness) and lesions of the gastrointestinal tract (followed by diarrhea). In addition, in older animals (17-28 weeks) a significant lack in growth, curvature of the spine and presence of chronic respiratory disease were observed, followed by coughing and breathing difficulties.

Furthermore, we have shown that PCV-2 presence is mostly specific to samples of lymph nodes and intestines, or to combined samples of these organs. Selection of the lung samples only is the least advisable. In addition, it can be assumed that the virus identification in animals' sperm is complicated. It can be associated with the selection of the virus with mentioned biological fluids only for a certain period of time (the period of viremia and significant immunosuppression). Consequently, this material is not recommended to be used for diagnostic and monitoring studies.

These research results indicate the possibility of detecting PCV-2 by PCR in all of the mentioned tissues, but with varying frequency. Although, it is impossible to establish a definite relationship between viruses and tissues that have been investigated.

As looking for distribution area of PCV-2 in Ukrainian during the period from 2007 to 2012, we can see that detection of cases number increases with the duration of the study (Fig.4). Thus, in 2007 in Donetsk regions PCV-2 was detected in 5 of 8 samples, yet during the period from 2007 to 2012 it was detected in 20 of 41 samples. Among 3 samples from Kyiv region PCV-2 was found only in 1 sample in 2007, but after the period from 2007 to 2010 it was in 10 from 21, and from 2007 to 2012 PCV-2 was found in 31 of 81 samples; not very high level of PCV-2 spread is shown in Kyiv region.

Next, as looking for Odessa and Vinnitsa regions, which were not studied at 2007, after the period from 2007 to 2011 PCV-2 was found in 3 of 5 and 2 of 4 samples, respectively. Yet, after 2012 in Odessa and Vinnitsa regions PCV-2 was found in 7 of 14 and 8 of 14 samples, respectively; that shows the high level of PCV-2 spread in these regions. Besides, Mykolaiv and Cherkassy regions show less level of PCV-2 spread: during the period from 2007 to 2012 virus was in 4 of 10 samples and in 7 of 26 samples, respectively, when in 2007-2010 was found only one case of PCV-2assocciated diseases. Zakarpatsky region is interesting, it had no enough research - during the period from 2007 to 2012 in this region PCV-2 was found only in 1 of 2 samples; therefore, we cannot say with confidence about the prevalence of PCV-2 in this region (Fig. 4).

Our assessment of the virus distribution let us state that the prevalence of PCV-2 on the territory of Ukraine is about $41 \%$, because it's pathogens were detected in 144 of 352 samples. The mentioned level is averaged and characterizes the areas where 16-30 samples were studied. Such index of mentioned pathogen distribution correlates with the facts obtained by researchers in other European countries.

Hence, during this research the material from pigs from 23 regions of Ukraine and Crimea was studied. Most samples, namely 81, were studied from Kyiv region. Next, 31 samples were positive for presence of PCV-2, and other 50 were negative, thus the frequency of the virus distribution in this area is about $38 \%$. Among 29 samples from Dnipropetrovsk region PCV-2 was found in 15 samples, which arranges $52 \%$; among 26 samples from Cherkassy region PCV-2 was found in 7, which arranges $27 \%$; in samples from Donetsk oblast virus was detected in 20 of 41, which arranges $49 \%$ of studied material.

Also, PCV -2 was found in 7 of 14, which arranges $50 \%$ samples from Odessa region; 4 of 8 samples $(50 \%)$ of Sumy region and in 12 of 33 samples (36\%) of Chernihiv region. The same prevalence of PCV-2 was observed in Poltava and Vinnitsa regions where the virus was detected in 13 of 28 samples, which arranges $46 \%$ and 8 of 14 samples (57\%), correspondently.

Meanwhile, in Zaporozhye and Kherson regions PCV-2 was identified in $25 \%$ and $42 \%$ of the samples, namely in 2 of 8 samples and 5 of 12 samples correspondently. The lower prevalence of PCV -2 was detected in Lviv and Kharkov regions in 2 of 6 and 2 of 8 samples, which arranges $33 \%$ and $25 \%$, and Mykolaiv region in 4 of 6 samples, which arranges $67 \%$. 4 of $5(80 \%)$ samples were positive in Ternopil' region.

Despite the fact that in Crimea and Volyn' regions PCV-2 was identified in $100 \%$ of the samples, it is impossible to establish the prevalence of the virus clearly in the mentioned territory, because it was examined only 1 or 2 samples from each farm in this area (Fig. 4). Also, 3 of 5 samples (60\%) was positive for PCV-2 in Kirovograd, and 1 of 2 (50\%) in Chernivtsi and Zakarpatsky regions. It is important to emphasize that it is impossible to state that the Zhitomir, IvanoFrankivsk and Luhansk regions are free from PCV-2 as it wasn't detected, as because from 2 to 4 samples were examined only. 


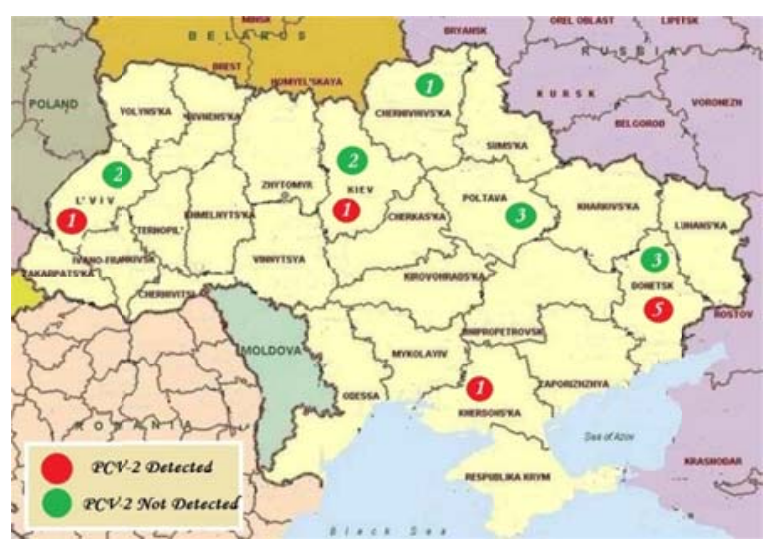

$a$

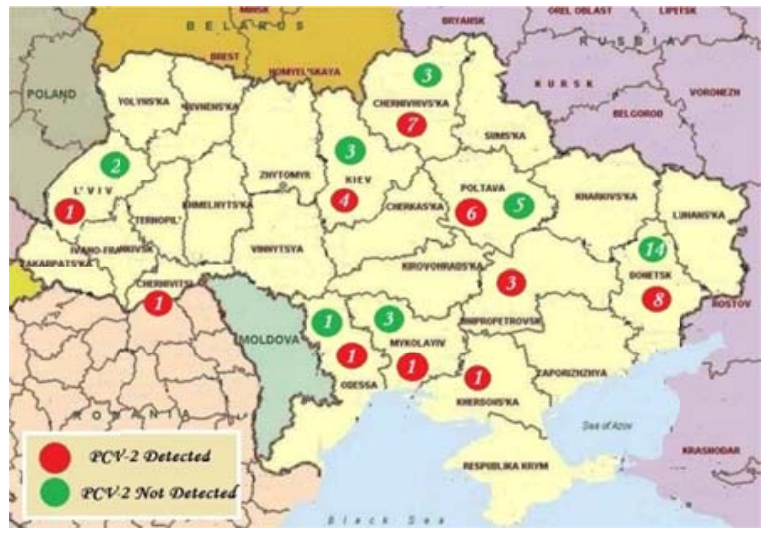

$c$

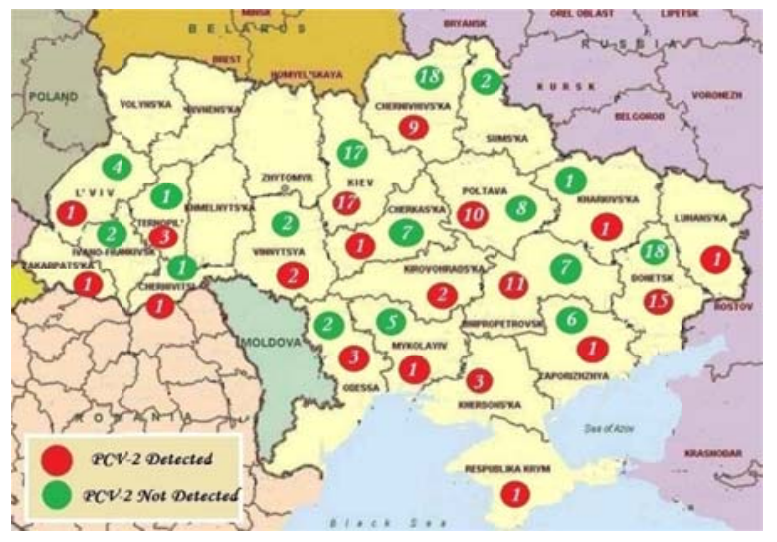

$e$

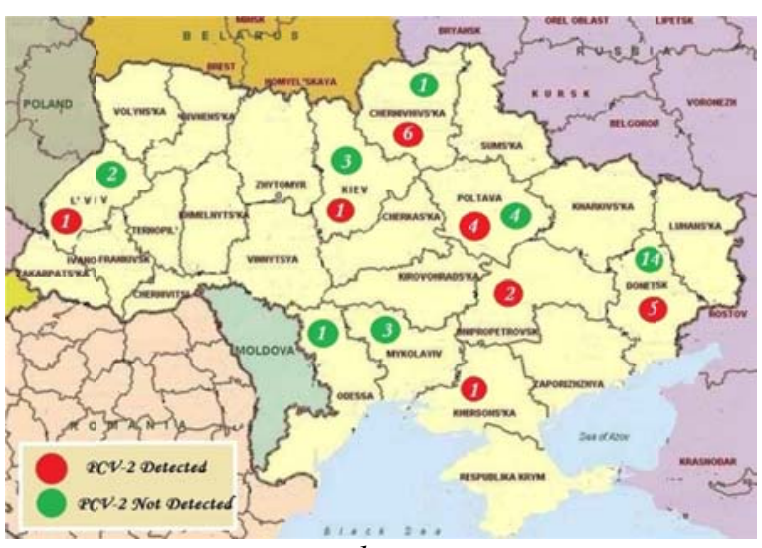

$b$

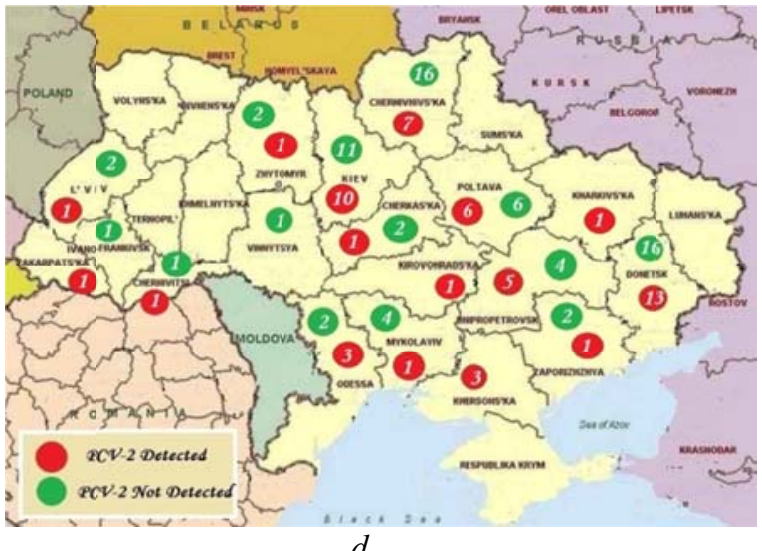

$d$

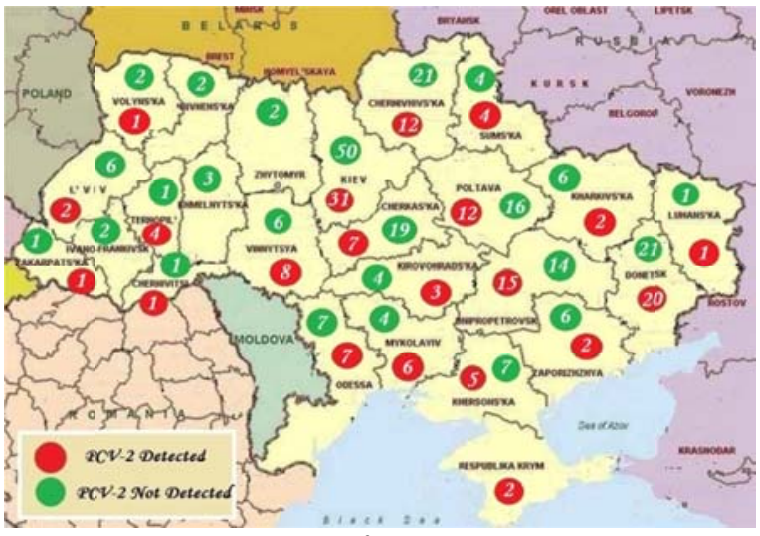

$f$

Fig. 4. Distribution area of PCV-2 in Ukrainian during the period from 2007 to 2012: $a$ - detection of PCV-2 in in Ukrainian during 2007; $b$ - detection of PCV-2 during 2007-2008; $c$ - detection of PCV-2 during 2007-2009; $d$ - detection of PCV-2 during 2007-2010; $e$ - detection of PCV-2 during 2007-2011; $f$ - detection of PCV-2 during 2007-2012

\section{Conclusion}

1. The research results indicate the possibility of detecting PCV 2 by PCR in all of the mentioned tissues, but with varying frequency. Although it is impossible to establish a definite relationship between viruses and tissues that have been investigated.

2. Summarizing the data of the described longterm and large-scale studies, we can state that PCV-2 is highly prevalent virus throughout the territory of Ukraine.
3. PCV-2 most common for Ternopil' (80\%), Kirovograd (60\%), Vinnitsa (57 \%), and Dnipropetrovs'k (52\%) regions, while it is less common in Kharkov (35\%), Cherkassy and Zaporizhya (both $27 \%$ ), and Lviv (33 \%) regions.

4. Some regions - like Zhitomir, IvanoFrankivsk and Luhansk regions and Volyn' - require a detailed study on the spread of the PCV-2.

\section{References}

1. Studies on epidemiology and pathogenicity of porcine circovirus / Tischer I. et. al. // Archives of Virology. 1986. Vol. 91, Issue 3-4. P. 271-276. doi: 10.1007/bf01314286

2. Hamel A. L., Lin L. L., Nayar G. P. Nucleotide Sequence of Porcine Circovirus Associated with Postweaning Multisystemic Wasting Syndrome in Pigs // Journal of Virology. 1998. Vol. 72, Issue 6. P. 5262-5267. 
3. Detection of a Novel Strain of Porcine Circovirus in Pigs with Postweaning Multisystemic Wasting Syndrome / Morozov I. et. al. // Journal of Clinical Microbiology. 1998. Vol. 36, Issue 9. P. 2535-2541.

4. Segales J., Allan G. M., Domingo M. Porcine circovirus diseases // Animal Health Research Reviews. 2005. Vol. 6, Issue 2. P. 119-142. doi: 10.1079/ahr2005106

5. Patterson A. R., Opriessnig T. Epidemiology and horizontal transmission of porcine circovirus type 2 (PCV2) // Animal Health Research Reviews. 2010. Vol. 11, Issue 2. P. 217-234. doi: 10.1017/s1466252310000162

6. Epidemiology and transmission of porcine circovirus type 2 (PCV2) / Rose N. et. al. // Virus Research. 2012. Vol. 164, Issue 1-2. P. 78-89. doi: 10.1016/j.virusres.2011.12.002

7. Phylogenetic analysis of porcine circovirus type 2 (PCV2) pre- and post-epizootic postweaning multisystemic wasting syndrome (PMWS) / Timmusk S. et. al. // Virus Genes. 2008. Vol. 36, Issue 3. P. 509-520. doi: 10.1007/s11262-008-0217-1

8. Porcine circovirus type 2 (PCV2): genetic variation and newly emerging genotypes in China / Guo L. J. et. al. // Virology Journal. 2010. Vol. 7, Issue 1. P. 273-285. doi: 10.1186/1743-422x-7-273

9. Phylogenetic and recombination analysis of genomic sequences of PCV2 isolated in Korea / Kim H. K. et. al. // Virus Genes. 2009. Vol. 39, Issue 3. P. 352-358. doi: 10.1007/s11262-009-0395-5

10. Porcine circovirus type 2 (PCV2) evolution before and after the vaccination introduction: A large scale epidemiological study / Franzo G. et. al. // Scientific Reports. 2016. Vol. 6, Issue 1. doi: 10.1038/srep39458

Дата надходження рукопису 09.01.2018

Lyudmila Dudar, Postgraduate student, Educational and Scientific Center "Institute of Biology and Medicine" of Taras Shevchenko National University of Kyiv, Akademika Hlushkova ave., 2, Kyiv, Ukraine, 03127 E-mail: liudmyla.dudar@hipra.com

Valery Polischuk, Doctor of Biological Sciences, Professor, Educational and Scientific Center "Institute of Biology and Medicine" of Taras Shevchenko National University of Kyiv, Akademika Hlushkova ave., 2, Kyiv, Ukraine, 03127

Iryna Sobko, Director, LLC "Center of Veterinary Diagnostics", Ushynskoho str., 25-A, Kyiv, Ukraine, 03151 E-mail: i.sobko@cvd.com.ua

Iryna Budzanivska, Doctor of Biological Sciences, Professor, Department of Virology, Educational and Scientific Center "Institute of Biology and Medicine" of Taras Shevchenko National University of Kyiv, Akademika Hlushkova ave., 2, Kyiv, Ukraine, 03127

E-mail: birishechka68@gmail.com 